Literature Reviews

\title{
Accounting Systems and Classifications: The Case of Greece
}

\author{
Athianos Stergios and Stylianou Tasos \\ Department of Economics, International Hellenic University, Greece
}

\author{
Article history \\ Received: 07-08-2018 \\ Revised: 25-09-2018 \\ Accepted: 20-12-2019 \\ Corresponding Author: \\ Athianos Stergios \\ Department of Economics, \\ International Hellenic \\ University, Greece \\ Email: astergios1@gmail.com
}

\begin{abstract}
In this study, we are trying to analyze the Greek accounting system and its features like the legal system, the taxation, the creative accounting the role of culture and the banking system. The legal system of Greece belongs to the code law family. Historically, the Greek accounting and commercial law have been heavily influenced by various French events and facts. In the Greek listed companies, the ownership concentration is high and the owners are directly involved in business administration. Therefore, they are able to watch and to motivate the staff without the need for programs of supply incentives. The tax system in Greece is a system of conflicting laws, judgments and ministerial decisions, which they attribute to special interests. Company law and tax law are in conflict and accountants tend to follow the latter. Greece (together with Austria) is classifying as the country (by total of 31) with the highest rank in profit manipulation. We are trying to report and analyze the concept and content of International Accounting Standards and in addition, we refer to the Greek Accounting Standards (GAAP) and fully analyze their content as defined by the relevant legislation of the country.
\end{abstract}

Keywords: Accounting Systems, Classification, Harmonization

\section{Introduction}

Two accounting models have been developed in the western world. In countries where the role of the state in the economy was limited (Common law), the AngloSaxon model was developed, while in the countries where the state had developed an important role in the economy (Code law), the French-German accounting model was adopted.

Common law was created in England during the 11th and 12th centuries and then spread from its colonies. The characteristic of the Common Law countries is that the shareholders of companies, whose rights to a large extent are protected. Common law countries, given that the state had a small contribution to the economy, followed the Anglo-Saxon accounting model which was developed in Great Britain and then in the United States (Ball et al., 2000; Ball, 2006). Also, in these countries the separation of accounting and tax rules is clear and the companies are preparing two different financial reports. A report that is prepared on the basis of IAS and addressed to all users of the financial statements, while the other report is prepared on the basis of the tax regulations and addressed to the tax authorities (Vlachos and Louka, 2009).

In common-law countries, the model of governance of one shareholder is the most possible (Kothari and
Short, 2003). In this model, ownership diffusion and separation often occur. Administration and the Board of Directors are typically not block holders, so they are managing the company without big ownership. In addition, workers and the government do not have high participation rates and they are rarely represented on the board. This creates demand for timely disclosure of financial data first, to reduce the asymmetry of information between managers and current and potential owners and secondly to monitor the performance of the executives. Traditionally United Kingdom, USA, Canada, Australia etc can be described as Common Law countries.

In Code law countries, the parties to the company (shareholders, customers, suppliers, managers, governments, creditors, employees) are recognized as "stakeholders" and the economies of these countries "stakeholder economy".

In the Code law countries where the state was playing a very important role in the economy, they have adopted the French-German accounting model which it was appeared in the 17 th century in France and was a result of the initiatives of the state.

The code law countries usually are carrying high political influence in the standard-setting bodies and in the introduction of accounting practices. For example, in Japan, the Business Accounting Deliberation Council 
(which advises the Ministry of Finance) creates code law accounting standards.

The Code defines regulations ranging from abstract principles to detailed procedures in relation to the application of accounting standards. The government applies the code law system and the criminal sanctions that may be imposed for violating the code law. The feature of this model is that in the published financial statements the tax rules are prevailed and, in general, there is a close relationship between taxation and accounting. This model has been adopted by many countries in Europe such as France, Germany, Belgium, Italy, Sweden, Austria, the Netherlands and Greece

Greece's accounting system has all the characteristics of an accounting system in the Continental Europe and can be classified as Code law country. Due to the strong political influence in setting the accounting standards, accounting profits are distributed to the "participants" of the companies without this creating a problem for the financial stability of the company. The way that it happens is for governments to collect taxes, for shareholders through dividends, to banks through interest-paying, to managers by giving bonus, to the employees with increases in wages (Ball et al., 2000). Based on the above stakeholders can determine the demand for accounting profits, which everyone for their own reasons, want less volatile accounting profits. So business executives have more freedom to smooth out accounting profits (Spathis and Georgakopoulou, 2007).

According to Ball et al. (2000) companies in the code law countries, for the raising of their funds are based on debt financing, with personal debt and not be issued or traded publicly. The main sources of funding are banks and other financial institutions, the state, managers and employees. The Stock markets are relatively small and less developed.

In these countries, there is a close relationship between companies and banks. Banks are the main users of financial statements as they provide the companies the biggest part of the funds. They have direct access to the financial statements of the companies since they are provided them either directly by the company's administrations or by the representatives in the Board of Directors. So the problem of asymmetric information is not solved through published financial statements, as in the case in the common law countries, but with the use of private information.

One other characteristic is that the concentration of corporate ownership is very high and mainly concentrated in institutions such as banks. On the other hand, because the rights of investors are not protected leads to reduced participation of the investors in business ownership. These two characteristics form of financing and ownership concentration, leads to poor financial information. So the businesses have fewer incentives to publish transparent and high-quality financial statements.
The role of the code law system is not limited to the influence it has on accounting standards. It also affects the corporate governance model which was developed at the same time as accounting standards and disclosure systems in these countries. Ball et al. (2000) argue that in the code-law countries, a governance model with the involvement of "stakeholders" is likely to be observed, composed of executives, employees, government and banks (as shareholders or lenders) as key contractors. The interest in this model of government is that the demand for disclosure of accounting information is decreasing because the representatives of "stakeholders" participate in it. The Representatives are generally informed due to the access to confidential information. This solves the problem of asymmetric information which usually is due to the superior knowledge of the executives of an enterprise against the other "participants". While the demand for disclosure information is reduced, the accounting statements in a governance system of «stakeholders» are possible to be affected by their payment of the representatives through labor, capital and government. Particularly, greater profit regulation and profit manipulation can be expected. The last requirement arises in part because the interested parties and in particular the managers and employees may own the minimum of the diversified (Diversification is the purchase of investment products with different risk and returns in order to reduce as much as possible the risk borne and to normalize a significant percentage of the volatility of the overall performance of a portfolio of risk balancing and performance equilibrium in a diversified portfolio is that overall performance may be somewhat lower (but more stable) than that of an undifferentiated portfolio) (undiversified) portfolio.

IAS/IFRS can be considered as a classic version of the Anglo-Saxon accounting model, since they are clearly influenced by culture and accounting practice of Common Law countries and are highly differentiated from Code Law countries which are applying the GalloGerman accounting model. The characteristic of IAS that lead to this view is that accounting rules are not affected by the tax claims and their primary priority is to meet the needs of the shareholders.

Ball et al. (2000) in their research are presenting data from 25 common law and code-law countries from 1985 to 1995 for over 40,000 companies. Evidence is according to the assumption that the governance model of one shareholder in common-law countries encourages the prompt disclosure of accounting information in relation to a stakeholder's model of governance in code law countries. The researchers found that the disclosure of bad news is particularly topical in a common-law environment. The reason is that the disclosure of bad news from the executives of the administration is more reliable and can provide useful information for the 
external suppliers of capital. In addition, the failure to uncover the bad news in time can cause litigation between the shareholders. The treatment of a shareholder is more likely to be successful if the claimants can yield the losses (or damages) to the no disclosure of the bad news from management, instead of claiming that they have suffered damage because executives did not disclose the good news.

The Greek Accounting Standards (IASs) are based on the International Accounting Standards (IAS) concept, with the difference that they are more simplified due to the limited nature of Greek-based enterprises. Our paper aims to report concisely and comprehensively the basic rules of the previous accounting systems and to analyze the accounting system which is currently in use in Greece, the Greek Accounting Standards. Through our research we are also aiming to highlight the advantages and disadvantages of this new accounting system in Greece.

\section{Materials and Methods}

\section{Historical Review of the Greek Accounting System}

The origin of accounting and bookkeeping has not been verified. A number of researchers in the history of accounting stated that the inventors of accounting and in particular the double-entry accounting system, were either the ancient Greeks or the Phoenicians. However, there are no historical elements either in Greek texts that survived through centuries or archaeological excavations, to support these theories. However, there are important indications that the Ancient Greeks had developed a complex system to monitor the financial data for the development of the resources by the public employees and elected officials. During the golden period of Athens, the reference of the word "accountant" and "calculus" used for first time and they used in a similar way, as in the present time. Later, Greece was captured by the Romans and when the Roman Empire was dissolved became part of the Eastern Roman (Byzantine) Empire (around the fourth century BC). This period of Greek History has never been properly researched and we have very little information about the organization of the economy. However, the Byzantine Empire had a very successful economy and that means that they must have some sophisticated mechanisms to monitor the economic issues; and therefore, some forms of accounting. During the Revolution 1821 against the Ottoman Empire, the National Communes of Epidaurus, Argos and Troizanas decided to adopt the French Trade Code of 1807 as a basis for the organization of the country's commercial life. After the liberation, in 1835, a translation of French Commercial Code was adopted by Greece as the Greek Commercial Code. It is noteworthy to mention that a big part of that code is used until today. Since then, the Greek commercial law and accounting have always (with a time lag) follow France. This culminated in the adoption in 1980, without any substantial change, of the French chart of accounts which constituted the Greek chart of accounts (Ballas, 1994).

\section{The Chart of Accounts}

The efforts to prepare the Greek chart of accounts lasted almost three decades. The first committee was founded in 1954, but eventually the statute of the accounts chart was enacted by law in 1980 (Law $1041 / 1980$ and the P.O.1123/1980). Finally, in September 1981, the whole text of the Greek chart of accounts was published. In June of 1987 a second version was published incorporating the changes for the adoption of the Fourth and Seventh Directive of the European Parliament. Originally, only those parts of the chart that referred to the presentation of financial statements were mandatory. However, from the first of January 1991 the law 1882/90 made the usage of General chart of accounts obligatory for companies controlled by members of the Chartered Accountants.

Its implementation was strengthened by the Tax Code which made it obligatory for all businesses, regardless of their legal form and with a turnover exceeding 180,000,000 Greek Drachmas to keep their books in accordance with the chart of accounts for Tax purposes, as well as for financial reporting. Finally, the adoption of the Greek General chart of accounts and the composition of the 4th and 7th Accounting Directives into national law (K.N. 2190/1920 and Greek General chart of accounts) have upgraded the accounting practices and Greece was harmonized with the French-German accounting model. In addition, the introduction of computerization to the accounting departments of the businesses has modernized the accounting sector (Bellas et al., 2007). The Greek General chart of accounts was characterized as the technological revolution in the field of accounting for Greece by adopting a common accounting language and accounting standardizations within the country (Sakellis, 2005). Also the Greek General chart of accounts facilitated the work of accountants and auditors, reduced the operational costs, increased the efficiency of accounting departments and channels the investing public with information through the financial statements (Tzanayos, 2008). The implementation of the General chart of accounts by the Greek companies has resulted in solving some controversial issues such as arbitrariness in accounting practices, effective communication between businesses and public administration and, finally the validity and credibility of business information (Ballas, 1994).

\section{The Legal System in Greece}

The legal system belongs to the code law family. Historically, Greek accounting and commercial law have 
been heavily influenced by several French events and facts (Ballas, 1994; Ballas et al., 1998). In 1980, in order to facilitate the process towards E.U membership, Greece has adopted a General chart of accounts based on the French chart of accounts. This has been modified in 1987, according to the 4th and 7th EU Directives (Ballas, 1994; Venieris, 1999).

Ballas et al. (1998) stated that the Greek chart of accounts was addressed to an international audience, while the issues of taxation and the compliance of accounting books were purely Greek. In fact, regarding the accounting legislation, the Greek state has demonstrated a significant degree of autonomy due to social interests (Ballas et al., 1998).

Interest groups are weak and the interest of professionals' bodies is indirect, through the members under the responsibility of the government (Venieris, 1999). The customer relations was a characteristic feature of the Greek state, with a lack of confidence and a perception that it is pursuing meeting the objectives of the sectors, despite the public interest (Charalambis, 1996). That leads to ambiguous behavior by its citizens: The pursuit of "favors" by the state and attempts to deceive the system. So the citizens are in a malicious circle that swirls towards more regulations as the state thinks what the citizens are going to do (Ballas et al., 1998). The only solution to overcome this problem is trust. High trust encourages spontaneous partnerships and reduces the need for State interference leading to the reduction of the monitoring costs. On the contrary, low trust leads to greater need for State interference and increase monitoring costs within the adoption of more complex laws and rules. Greece is a low-trust society, which does not contribute to self-regulation accounting or trust in the "true and fair view" of economics situations, but requires state regulation and comprehensive rules which are increasing monitoring costs and distrust (Ballas et al., 1998). That leads to a "formalism", which is defined as "an excessive adherence on predefined forms and the use of special documents without taking in account the internal importance "(Ballas et al., 1998).

\section{Taxation, Creative Accounting and the Role of Culture}

The tax system in Greece is "a cloudy system of conflicting laws, judgments and ministry decisions, which clearly yield to special interests" (Ballas, 1994). The financial information is traditionally closely related to taxation (Michalatos, 2001; Tzovas, 2006) and their main link is Tax Law (Presidential Decree 186/92 - also known as the Code of Books and Elements). The close relationship between accounting and taxation and the fact that taxes are considered to be unjustly high, has the effect of tax avoidance and evasion and creative accounting (Baralexis, 2004). For example, the research of Tsakumis et al. (2007) stated that black economy is estimated to be around $40 \%$ of the Gross Domestic Product - the largest in the European Union, for the 1997. Papas (1993) suggest that where corporate law and tax law is in conflict, the accountants tend to follow the last. One more reason for the companies to comply with the requirements of tax law is the strict fines that the tax authorities imposing in the case of non-compliance. On the contrary, non - compliance with the company law requirements do not lead to severe penalties. In fact, the penalty is a condition in the audit report (Papas, 1993) which usually is not taken into account. Fillios (1995) reports that since 1920 there have not been a penalty imposed on an accountant for non-compliance with company law regulations.

Tsakumis et al. (2007) find among others that the profile of a country with a high rate of tax evasion is characterized by high avoidance of uncertainty. The most common example of tax avoidance is the tendency that the forecasts are not recognized until they are realized because they are not deductible for tax purposes (Caseley, 1996). Greece is the country with the highest rating on the characteristic of avoiding uncertainty according to the study of Hofstede (1983). Gray (1988) ranks Greece in the group of countries of the Middle East whose main features are the strong conservatism and confidentiality, state control and uniformity. Although Greece is expected to move to different accounting values (Leventis, 2001), uniformity and confidentiality are still considered to be highly prevalent (Tsakumis et al., 2007). This and the above examples referring to avoidance of tax can provide support for Nobes (1998) argument that the culture can be seen as a key factor for the development of an accounting system in a country in general and in Greece in particular.

Creative accounting and profit management practices are well documented in the bibliography (Spathis, 2002; Spathis et al., 2002; Leuz et al., 2003; Baralexis, 2004; Caramanis and Spathis, 2006; Burgstahler et al., 2006). In fact, Leuz et al. (2003) rank Greece (along with Austria), as the country (out of a total of 31) with the highest rank in profit management. Ghicas et al. (2008) provide an example for the impact of creative accounting practice. For a sample of 149 companies, if the impact of the auditor's qualifications had been recognized in last year, "would have reduced profits by $21 \%$ and the book value of own funds would be reduced by $4.4 \%$ ". This is particularly important during the test of the frequency of the specific audit report. This background explains the reason why the banks are not based on the published financial statements for borrowing decisions. They lend according to the ability of companies to provide a guarantee (Fillios, 1995). 
Ownership is high and owners are directly involved in business management. They are therefore able to monitor and motivate staff, without the need for incentive programs. There is also less need for using financial statements as a means of communicating with the owners (Tzovas, 2006). As a result, ownership concentration contributes to the adoption of an aggressive reduction in the tax strategy, as their ownership status does not seem to generate significant non-tax costs. Tax adjustments (such as accelerated depreciation) in the financial statements (Venieris, 1999) are distorting further the results of the companies. In addition (and as is the case with other code law countries), the demand for accounting income is heavily influenced by the preferences of payments of the various stakeholder groups. Because these stakeholders prefer less volatile profits, companies in code-law countries tend to have more room for income normalization (Spathis and Georgakopoulou, 2007).

\section{International Accounting Standards}

In February 2010, The European Union (EU) anticipated a regulation upon every listed company on EU stock exchange markets which requires them to draft consolidated financial statements correspondingly with International Accounting Standards (IASs), to be updated as International Financial Reporting Standards (IFRS) (Albu et al., 2011; Doukakis, 2010; Liu, 2011). As soon as this regulation took place effectively in 1 January 2005 (Doukakis, 2010), approximately 7000 European listed companies were obligated to apply IFRSs for their financial reporting systems (Callao et al., 2009). Other developing countries have followed the EU by exercising this regulation, especially countries that expect continuity in their foreign investments (Al-Shammari et al., 2008).

The IAS/IFRS are considered as a system oriented towards the shareholder, with the presentation of financial statements that is fair value based (Alexander and Archer, 2001). Meanwhile, the volatility in book values and reported earnings are likely to be introduced by the fair value orientation of IAS/IFRSs (Barth et al., 2006; Hung and Subramanyam, 2007). For instance, the measurement of the liabilities at the higher fair value and the amount recognized by IAS/IFRS as long as their fair value is measured reliably, (Al-Yaseen and Aldeen Al-Khadash, 2011). As though, assets are measured at the lower of fair value and the best estimate that can be ascertained for an amount for future settlement (Songlan and Kathryn, 2010).

Theoretically having more informative and comparable financial reports due to the adoption of IFRS is expected to lessen the need for foreign expertise to analyze these financial reports; consequently, this should lead to more cross-border investments. Empirically Covrig et al. (2007) revealed in his study higher significance of foreign mutual fund ownership for voluntary IFRS implementers compared to GAAP in banks. Moreover, findings suggested a possibility of firms to attract foreign investments after implementing IFRS. Chen et al. (2014) investigated IFRS adoption in light of international cross-listing. Results confirmed slightly more significance to cross-list for countries mandatorily adopting IFRS. Also, firms located in places where IFRS adoption is mandatory are more likely to cross-list their securities in other countries obligating IFRS. The influence and benefits were less in countries with accounting practices different from IFRS due to less access to foreign capital and fewer disclosure requirements prior to IFRS adoption.

\section{Greek Accounting Standards}

With effect as of 1 January 2015, Law 4308/2014 as in force currently, has introduced significant changes and novelties compared to the previously applicable Greek Accounting Standards and fiscal framework. Interpretative guidelines are in place which were issued back in December 2014 but also most recently in October 2015. The new Accounting Standards establish bookkeeping and financial statements obligations that are based on IFRS principles, although with some differences to the direction of more "flexible" treatment e.g., the optional application of deferred taxation. The adoption of full IFRS, instead of the new Greek Accounting Standards, is optional, subject to management decision, except for specific undertakings that are obliged to adopt full IFRS (Law 4308/2014 exhaustively lists these cases). Nevertheless, once adopted, IFRS should be applied consistently for at least five consecutive fiscal years. Companies are further subject to different compliance obligations depending on the size of the undertaking based on specific quantitative criteria (total value of balance sheet, net turnover and average number of employees of the undertaking). The volume of these obligations is escalated from microundertakings to large undertakings, while for smaller undertakings special exemptions and simplifications apply. Either under the Greek Accounting Standards or the IFRS, the accounting system used by the undertaking must monitor in parallel both the accounting and tax basis of expenses, revenues, assets, liabilities and equity elements, in order to be in compliance with tax legislation. The Interpretative Circular indicates specific methodologies and examples for the fulfillment of such requirement; the most representative one is the dual monitoring of depreciations per the useful life accounting standard and per the tax rules depreciation rates applicable for tax purposes. What is more, the new law contains "illustrative" financial statements, individual and consolidated models thereof. The obligation to draft consolidated financial statements 
depends on the categorization of Groups into small, medium-sized and large, based on specific thresholds. New requirements are also set in relation to the drafting of Notes to the accounts which should provide detailed information (narrative and quantitative) regarding the financial statements' accounts/figures, depending again on the size of the undertaking. A further area that has been subject to significant amendments under the new law is the measurement and recognition rules. Most of the amendments in this area are in line, if not totally similar, with IFRS respective rules. Some key aspects of these rules are outlined below:

- Depreciation may be calculated based on the estimated useful economic life of assets instead of deemed tax depreciation rates applicable for tax purposes only from now on

- Assets can be subject to impairment

- Leases are categorized as financial or operating, depending on the economic substance criteria set by the IFRS and also reflected in tax law (previously all operating leases were not possible to be re-qualified)

- Provisions for employees' severance indemnity are measured either based on the nominal amounts according to employment legislation or based on accepted actuarial studies

- $\quad$ Establishment expenses, R\&D expenses and income tax (current and deferred) constitute elements of the $\mathrm{P} / \mathrm{L}$ statement

Additional IFRS inspired principles that have been introduced are the materiality and going concern concept, fair value measurement and deferred taxation. For those applying the new Accounting Standards, interpretative guidance may also be sought from the IFRS, as long as same is in line with the provisions of the new law. The transition procedure will involve the restatement of items of the previous two Fiscal Years as well, so that the comparative figures are in line with the new standards, as it would be the case upon the implementation of IFRS ("first time adoption"). The volume of work involved will depend largely on the type of business of a company as well as the items affected. The law and interpretation thereof, however, provide for some exemptions and simplifications upon the initial adoption of these new standards considering the cost and administrative burden that may be raised for Greek undertakings due to this transition, especially for smaller ones. It is believed that the introduction of the New Greek Accounting Standards is a first step towards IFRS and that in the future the adoption of the IFRS in full may become obligatory for all Greek undertakings. Despite the cost and technical expertise necessity, this may prospectively enhance the comparability and reliability of Greek undertakings' financial information as well as facilitate consolidation procedures for multinationals operating in Greece.

\section{Advantages and Disadvantages of Applying Greek Accounting Standards}

The advantages of achieving convergence with Greek Accounting Standards are numerous:

The law incorporates the accounting provisions of Directive 34/2013/EU with completeness and correctness into national law. Thus, the alignment of the national accounting framework with international accounting practices is achieved. An accounting system is introduced, which is understandable from the international market. Its implementation can be an essential tool for businesses in seeking opportunities both at national and international level. The financial statements are disconnected, or at least it's given the possibility, by tax legislation and better reflects the real economic position of businesses, thus inspiring greater confidence and achieving better comparability in the interests of healthy competition.

The Greek Accounting Standards aims to consolidate, supplement and update the accounting rules (articles 1624) of the country in order to create a comprehensive and functional accounting framework for business and other underlying entities

Furthermore they are fighting accounting multiplicity. For first time, all accounting rules are compiled into a law structured on the basis of the best practices for all businesses and accountants. The codification of the tax provisions of all accounting provisions, whether included in the CL. 2190/1920, either included in the GAAP, or introduced as newer provisions of Directive 2013/34/EU, or are formulated for first time by the legislator, constitute an important reforming step.

Also it provides general application by all entities without significant exceptions. Particular account has been taken for the European Union's principle for "small business priority" for reducing administrative costs.

It serves the need for transparency, reliability and comparability of financial information, which, along with legal certainty, creates conditions that contribute to the smooth operation of the market. Moreover, its implementation helps to attract foreign investment and capital, as the financial data included in the financial statements of Greek companies can be in line with international accounting rules.

According the literacy the disadvantages are summarized as follows:

The entire structure of the accounting standardization provided by the P.D. 1123/1980 (GAAP) is being demolished and its position gets an accounting model with a draft of accounts with no rules regulating their content and their operation, since it includes a patchwork of rules extracted from the GAAP 
from the Anglo-Saxon accounting model, in which the general and Analytical Accounting are being operated, by Directive 2013/34/EU and by the IFRS.

The costs associated with the requirements resulting from its application are increased. It overturns the accounting organization of businesses with full accounting reorganization at a very significant cost. Such costs are the cost of adjusting the accounting system, staff training costs, valuation costs of fixed assets. Finally, the accounting model excludes the preparation of the general holding account. In other words, it disregards the fact that the general holding account is an important tool in the hands of the management of companies for overall reliable information and support of the annual results in any tax or other control by the public administration.

\section{Conclusion}

In Greece, the first attempts to classify the accounting system began in 1954 and in 1980 the Greek chart of accounts was established. The Greek chart of accounts cannot be included in any of the known categories of the accounting systems but it could be included in the systems with an orientation towards the French chart of accounts. In fact, it was developed on the basis of the French. In Greece, the introduction of accounting rules is mostly a bureaucratic and at the same time a detailed procedure, as financial information is guided by the need for businesses to be accountable to Public Economic Services and on the other hand, to achieve income normalization. It could be said that the Greek Accounting System is distinguished from its conservatism and seeks to satisfy the needs of the interested parties of a business ("stakeholder - oriented").

Two accounting models have been developed in the western world. In countries where the role of the state in the economy was limited (Common law), the AngloSaxon model was developed, while in the countries where the state had developed an important role in the economy (Code law), the French-German accounting model was adopted. The Greek General chart of accounts was characterized as the technological revolution in the field of accounting for Greece by adopting a common accounting language and accounting standardizations within the country. The institutional framework in which accounting is applied in Greece is quite particular. The legal framework that defines accounting standardization and tax law forms an implementation framework not found internationally.

The last changes regarding the Greek Accounting System appeared a few years ago. With effect as of 1 January 2015, Law 4308/2014 as in force currently, has introduced significant changes and novelties compared to the previously applicable Greek Accounting Standards and fiscal framework. Interpretative guidelines are in place which were issued back in December 2014 but also most recently in October 2015. It is believed that the introduction of the New Greek Accounting Standards is a first step towards IFRS and that in the future the adoption of the IFRS in full may become obligatory for all Greek undertakings. Despite the cost and technical expertise necessity, this may prospectively enhance the comparability and reliability of Greek undertakings' financial information as well as facilitate consolidation procedures for multinationals operating in Greece.

\section{Author's Contributions}

Athianos Stergios: Participated to design of the paper and contributed to the writing of the research paper. Also involved in technical review based on practical and research experience.

Stylianou Tasos: Resources - Data collection and contributed to the writing on the research paper.

\section{Ethics}

This article is original and contains unpublished material. The corresponding author confirms that all of the other authors have read and approved the manuscript and no ethical issues involved.

\section{References}

Albu, N., C.N. Albu, S. Bunea, D.A. Calu and M.M. Girbina, 2011. A story about IAS/IFRS implementation in Romania. J. Account. Emerg. Econom., 1: 76-100.

Alexander, D. and S. Archer, 2001. European Accounting Guide. 4th Edn., Aspen Law and Business, Gaithers Bury, New York.

Al-Shammari, B., P. Brown and A. Tarca, 2008. An investigation of compliance with international accounting standards by listed companies in the gulf co-operation council member states. Int. J. Account., 43: 425-447. DOI: 10.1016/j.intacc.2008.09.003.

Al-Yaseen, B.S. and H.A. Al-Khadash, 2011. Risk relevance of fair value income measures under IAS 39 and IAS 40. J. Account. Emerg. Economic, 1: 9-32. DOI: $10.1108 / 20421161111107831$

Ball, R., 2006. International Financial Reporting Standards (IFRS): Pros and cons for investors: Accounting and business research. International Accounting Policy Forum.

Ball, R., S. Kothari and A. Robin, 2000. The effect of international institutional factors on properties of accounting earnings. J. Account. Econom., 29:1-52. DOI: 10.1016/S0165-4101(00)00012-4

Ballas, A.A., 1994. Accounting in Greece. Eur. Account. Rev., 3: 107-121.

Ballas, A.A., D. Hevas and D. Neil, 1998. The state of accounting and the state of the state. J. Manage. Governance, 2: 267-285. 
Baralexis, S., 2004. Creative accounting in small countries: The Greek case. Managerial, Audit. J., 19: 440-461. DOI: 10.1108/02686900410524427

Barth, M.E., W. Landsman, M. Lang and C. Williams, 2006. Accounting quality: International accounting standards and US-GAAP. Manuscript, Stanford Uni.

Bellas, A., K. Toudas and C. Papadatos, 2007. The consequences of applying International Accounting Standards (IAS) to the financial statements of Greek companies. Proceedings of the 30th Annual Congress of European Accounting Association, Apr. 25-27, Lisbon, Portugal.

Burgstahler, D., L. Hail and C. Leuz, 2006. The importance of reporting incentives: Earnings management in European private and public firms. Account. Rev., 81: 983-1016.

Callao, S., C. Ferrer, J.I. Jarne and J.A. Lainez, 2009. The impact of IFRS on the European Union: Is it related to the accounting tradition of the countries? J. Applied Account. Res., 10: 33-55.

Caramanis, C. and C. Spathis, 2006. Auditee and audit firm characteristics as determinants of audit qualifications: Evidence from the Athens stock exchange. Managerial Audit. J., 21: 905-920.

Caseley, H.R., 1996. Greece, in Alexander D. and Archer S. (Eds.). Eur. Account. Rev., 6: 85-108.

Charalambis, D., 1996. The relationship of the private and public in the Greek political system. Sakis Karagiorgis Foundation, Athens.

Chen, L., J. Ng and A. Tsang, 2014. The effect of mandatory IFRS adoption on international crosslistings. Account. Rev., 90: 1395-1435.

Covrig, V.M., M.L. Defond and M. Hung, 2007. Home Bias, foreign mutual fund holdings and the voluntary adoption of international accounting standards. J. Account. Res., 45: 41-70.

DOI: 10.1111/j.1475-679X.2007.00226.X

Doukakis, L.C., 2010. The persistence of earnings and earnings components after the adoption of IFRS. Managerial Finance, 36: 969-980. DOI: $10.1108 / 03074351011081286$

Fillios, B., 1995. Accounting for economic growth. Modern Publishing, Athens.

Ghicas, D.C., A. Papadaki, G. Siougle and T. Sougiannis, 2008. The relevance of quantifiable audit qualifications in the valuation of IPOs. Rev. Account. Stud., 13: 512-550. DOI: 10.1007/s11142-007-9051-2

Gray, S., 1988. Towards a theory of cultural influence on the development of accounting systems internationally. Abacus, 24: 1-15. DOI: 10.1111/j.1467-6281.1988.tb00200.x

Hofstede, G., 1983. The cultural relativity of organisational practices and theories. J. Int. Bus. Stud., 14: 75-89.

DOI: $10.1057 /$ palgrave.jibs.8490867
Hung, M. and K.R. Subramanyam, 2007. Financial statement effects of adopting international accounting standards: The case of Germany. Rev. Account. Stud., 12: 623-657. DOI: 10.1007/s11142-007-9049-9

Kothari, S.P. and J. Short, 2003. The effect of disclosures by management, analysts and financial press on the equity cost of capital. Working Paper 195, Centre for e-Business, Massachusetts Institute of Technology, Sloan School of Management, USA.

Leuz, C., D.J. Nanda and P.D. Wysocki, 2003. Earnings management and investor protection: An international comparison. J. Financ. Econom., 69: 505-527. DOI: 10.1016/S0304-405X(03)00121-1

Leventis, S., 2001. Voluntary disclosure in a European emerging capital market: The case of the athens stock exchange. PhD Thesis, Strathclyde University, UK.

Liu, C., 2011. IFRS and US-GAAP comparability before release no. 33-8879: Some evidence from US-listed Chinese companies. Int. J. Account. Inform. Manage., 19: 24-33. DOI: 10.1108/18347641111105917

Michalatos, D., 2001. Greece, in European Accounting Guide. 4th Edn., Miller, Aspen Law and Business, New York.

Nobes, C., 1998. Towards a general model of the reasons for international differences in financial reporting. Abacus, 34: 162-187. DOI: 10.1111/1467-6281.00028

Papas, A., 1993. Group Accounting in Greece. In: International group accounting: Issues in European Harmonisation, Gray, S.J., A. Coenenberg and P. Gordon (Eds.), Routledge Publications, London, pp: 121-134.

Sakellis, I.E., 2005. Compilation of the financial statements provided by international accounting standards based on the Greek general accounting plan. Sakellis Publishing, Athens.

Songlan, P. and B. Kathryn. 2010. Adaptability to fair value accounting in an emerging economy: A case study of china's ifrs convergence. Account. Audit. Accountability J., 23: 982-1011. DOI: $10.1108 / 09513571011092529$

Spathis, C., M. Doumpos and C. Zopounidis, 2002. Detecting falsified financial statements: A comparative study using multicriteria analysis and multivariate statistical techniques. Eur. Account. Rev., 11: 509-535. DOI: 10.1080/0963818022000000966

Spathis, C. ans E. Georgakopoulou, 2007. The adoption of IFRS in South Eastern Europe: The case of Greece. Int. J. Finan. Serv. Manage., 2: 50-63. DOI: 10.1504/IJFSM.2007.011671

Spathis, C.T., 2002. Detecting false financial statements using published data: Some evidence from Greece. Managerial Audit. J., 17: 179-191. DOI: $10.1108 / 02686900210424321$ 
Tsakumis, G.T., A.P. Curatola and T.M. Porcano, 2007. The relation between national cultural dimensions and tax evasion. J. Int. Account. Audit. Taxat., 16: 131-147. DOI: 10.1016/j.intaccaudtax.2007.06.004

Tzanayos, D., 2008. International accounting standards in simple words and their differences from Greek. Kastaniotis Publications, Athens.

Tzovas, C., 2006. Factors influencing a firm's accounting policy decisions when tax accounting and financial accounting coincide. Managerial Audit. J., 21: 372-386. DOI: 10.1108/02686900610661397
Venieris, G., 1999. Greece. In: Accounting Regulation in Europe, McLeay, S. (Ed.), Macmillan Press Ltd., London, UK, pp: 147-176.

Vlachos, C. and L. Loukas, 2009. International accounting standards. A and B., Papazisis, Athens. 